\title{
OBITUARY
}

\section{Nilmar Janbu}

Nilmar Janbu, Emeritus Professor of geotechnical engineering at the Norwegian University of Science and Technology, passed away peacefully in Trondheim, Norway on 4 January 2013 , at the age of 91 years.

Nilmar, as his friends and colleagues called him, was born on Bjørnsund, a small island off the west coast of Norway on 23 August 1921. He took his college exams at Eids Gymnas (a 1-day trip from home) in 1941 and started studying architecture at the Norwegian Institute of Technology (NTH, later the Norwegian University of Science and Technology). He soon switched his studies to civil engineering and obtained his degree in 1947. He continued at the university as a research assistant in structural mechanics. In 1948 he received a grant from the Norway-America Association to carry out 'postgraduate' work in the USA.

At Harvard University in Cambridge, Janbu was advised to focus on geotechnical engineering instead of suspension bridge structures as he originally intended. He thus came into the circle of Professors Karl Terzaghi and Arthur Casagrande, who had worked in the field since the 1920s and 1930s, and who are considered to be the founders of modern soil mechanics. Janbu obtained his MSc degree at Harvard in the autumn of 1949. His efforts and results were noticed and he obtained a 1-year scholarship to start doctoral studies. During the first year he took the necessary exams and made an approved first draft of his dissertation. He performed further work on his doctoral thesis as a research fellow at the Norwegian Institute of Technology, as an employee at Bonde and Co., Oslo and from 1952 as an employee at the newly established Norwegian Geotechnical Institute. The remainder of his doctoral thesis was done at Harvard in the autumn of 1953 and completed in January 1954.

Until 1961 Janbu was employed by the Norwegian Geotechnical Institute's office in Trondheim, with additional responsibility for teaching soil mechanics and foundation engineering at the University as Adjunct Professor. When the Geotechnical Division at NTH was established in 1961, Janbu was appointed Full Professor of Geotechnical Engineering. Janbu was an enthusiastic lecturer and communicator who rapidly captured students' interest in the subject. More than 300 students took their masters theses at the Geotechnical Division with Janbu as a teacher and mentor. Within 5 years the Geotechnical Division consisted of nine people, as well as laboratory and field equipment. Janbu's teaching and research were undoubtedly important for the strong reputation that Norwegian geotechnical engineering gradually gained nationally and internationally. Cooperation and contact with universities and institutions in the USA and Europe developed greatly under his leadership.

Janbu had a pronounced curiosity for people and physical phenomena. The lucky ones of us who had the opportunity to co-operate with Nilmar for almost half a century will never forget his accommodating attitude and enthusiastic support, regardless of whom he engaged with. Numerous visitors from all over the world now express their gratitude for being so naturally and heartily welcomed in Trondheim. We, his colleagues, never stopped admiring how he transformed deeply depressed students on the edge of giving up on their research, into shining-eyed, self-confident masters candidates, by pointing out how interesting and unexpected the findings they had made were. It was a great pleasure to work with

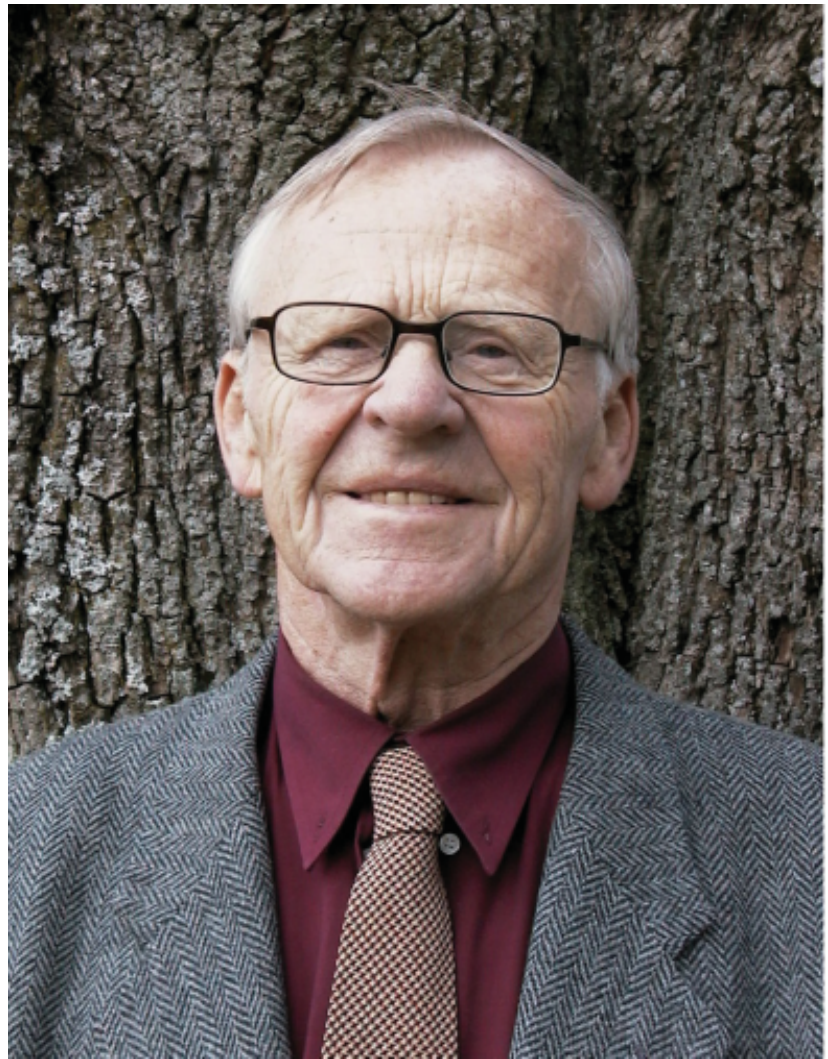

Professor Nilmar Janbu (1921-2013)

Nilmar. The spontaneous blackboard discussions on basic and particular issues are precious memories for us all.

Characteristic of Nilmar Janbu was his ability to apply theoretical knowledge to practical problems, as well as extracting the important features in complex phenomena. Therefore, he has worked as an advisor and problem solver for both private companies and public institutions. This was especially the case when oil production in the North Sea began in the 1970s, and Professor Janbu and colleagues at the Geotechnical Division were asked to assist in connection with the foundations of the huge constructions that were placed on the bottom of the North Sea. This activity called for the hiring of more researchers, forming a consulting group associated with the university group. In 1985 this group amounted to 14 engineers and researchers and was embodied into Sintef. At its peak Janbu and Senneset headed a total group of 25 people.

Janbu's doctoral dissertation on stability of slopes, for which he was awarded Austen B. Mason's distinguished prize at Harvard University, may have made him best known as a slope stability expert. His stability charts demonstrate how complex practical problems can be treated with adequate accuracy by concentrating on the basic factors, bulking the non-significant aspects. His urge to avoid unnecessary complications was also clear in his adherence to the principle of effective stress and his unifying classical resistance concepts for characterising oedometric soil behaviour.

Janbu has been active as a guest lecturer in a number of countries, including Australia, Brazil, Canada, India, Japan, 
China, Russia and the USA. In 1985 he was invited to give the prestigious Rankine lecture at Imperial College, University of London. The theme was the foundation and solutions related to offshore structures. He wrote about 130 scientific publications and papers covering a wide range of topics in geotechnical science and engineering.

After his official retirement in 1991, at 70 years of age, he still came regularly to his office and was as usual ready to give his advice and guidance to students and colleagues. He continued his scientific work and consulting as long as his health allowed him.

We remember Nilmar Janbu with respect and gratitude. Lars Grande and Kåre Senneset, Norwegian University of Science and Technology 